\title{
KAJIAN PENGGUNAAN DANA DESA DALAM PROGRAM PEMBERDAYAAN MASYARAKAT DI KECAMATAN SONDER
}

\author{
Ferly Rayen Runtu \\ Caroline Betsi Diana Pakasi \\ Lyndon Reindhardt Jacob Pangemanan
}

\begin{tabular}{ll}
\hline Naskah diterima melalui Website Jurnal Ilmiah agrisosioekonomi@unsrat.ac.id & : Kamis, 17 Oktober 2019 \\
Disetujui diterbitkan & : Kamis, 24 Oktober 2019 \\
\hline
\end{tabular}

\begin{abstract}
The purpose of this study was to determine the use of village funds in community empowerment programs in 8 villages, which were chosen deliberately (purposive sampling) from 19 villages in Sonder District. This research lasted for 2 months from October to November 2018. The data used in this study are primary data and secondary data. Primary data is data obtained from interviews with 4 respondents per village selected based on accidental sampling so that the total number of respondents from 8 villages is 32 community members. The interview was intended to find out the opinion of the community about the use of village funds. Secondary data in this study is data obtained from the APBDES document (Village Budget and Revenue). Data analysis method in this research uses descriptive method. The results showed the use of village funds in Sonder Subdistrict for physical programs amounted to 14 types of activities and for empowerment programs amounted to 15 types of activities. Therefore the total activities amounted to 29 activities. The opinion of the community who stated agreed on the openness of the village government to the village funds amounted to $68.75 \%$ and $31.25 \%$ of the community stated disagree. The community stated that they agreed to use the village funds for development programs amounted to $75 \%$ and $25 \%$ of the community disagreed. The opinion of the community that stated that the development program was approriate amounted to $78.12 \%$ and $22.88 \%$ of the community stated that it was not appropriate. ${ }^{*}$ eprm*
\end{abstract}

Keywords: village funds, community empowerment, community opinion

\section{ABSTRAK}

Tujuan penelitian ini adalah untuk mengetahui penggunaan dana desa dalam program pemberdayaan masyarakat di 8 Desa, yang dipilih secara sengaja (purposive sampling) dari 19 desa yang ada di Kecamatan Sonder. Penelitian ini berlangsung selama 2 bulan dari bulan Oktober sampai bulan November tahun 2018. Data yang digunakan dalam peneltian ini adalah data primer dan data sekunder. Data primer merupakan data yang diperoleh dari wawancara kepada 4 responden per desa yang dipilih berdasarkan kebetulan (accidental sampling) sehingga jumlah seluruh responden yang berasal 8 desa sebanyak 32 anggota masyarakat. Wawancara dimaksudkan untuk mengetahui pendapat masyarakat tentang penggunaan dana desa. Data sekunder dalam penelitian ini merupakan data yang diperoleh dari dokumen APBDES (Anggaran Pendapatan dan Belanja Desa). Metode analisis data dalam penelitian ini menggunakan metode deskriptif. Hasil penelitian menunjukkan penggunaan dana desa yang ada di Kecamatan Sonder untuk program fisik berjumlah 14 jenis kegiatan dan untuk program pemberdayaan berjumlah 15 jenis kegiatan. Jadi total kegiatan berjumlah 29 kegiatan. Pendapat masyarakat yang menyatakan setuju mengenai keterbukaan pemerintah desa akan dana desa sebesar $68,75 \%$ dan 31,25\% masyarakat menyatakan tidak setuju. Pendapat masyarakat yang menyatakan setuju akan penggunaan dana desa untuk program pembangunan sebesar $75 \%$ dan $25 \%$ masyarakat menyatakan tidak setuju. Pendapat masyarakat yang menyatakan sesuai dengan program pembangunan sebesar $78,12 \%$ dan $22,88 \%$ masyarakat menyatakan tidak sesuai. ${ }^{*}$ eprm*

Kata Kunci: dana desa, pemberdayaan masyarakat, pendapat masyarakat 


\section{PENDAHULUAN}

\section{Latar Belakang}

Undang-undang Nomor 23 tahun 2014 tentang Pemerintah Daerah, dan Peraturan Pemerintah Nomor 43 tahun 2014 tentang Peraturan Pelaksanaan Undang-Undang Nomor 6 tahun 2014 tentang Desa berdasarkan ketentuan ini desa diberi pengertian sebagai desa dan desa adat atau yang disebut dengan nama lain, selanjutnya di sebut Desa adalah kesatuan masyarakat hukum yang memiliki batas wilayah yang berwenang untuk mengatur dan mengurus urusan pemerintahan, kepentingan masyarakat setempat berdasarkan prakarsa masyarakat, hak asal usul, dan hak tradisional yang diakui dan dihormati dalam sistem pemerintahan Negara Kesatuan Republik Indonesia.

Pemahaman desa sebagai suatu organisasi pemerintahan yang secara politis memiliki kewenangan untuk mengatur dan mengurus warga atau komunitasnya dalam penyelenggaraan pemerintahan di tingkat desa. Posisi Desa memiliki peran yang sangat penting dalam menunjang kesuksesan pemerintahan nasional, karena desa merupakan garda terdepan dalam menggapai keberhasilan program yang direncanakan oleh Pemerintah.

Sebagian besar penduduk Indonesia saat ini masih bertempat tinggal di kawasan pemukiman pedesaan, oleh sebab itu akan sangat logis apabila pembangunan desa menjadi prioritas utama kesuksesan pembangunan dan program-program pemerintah dalam mengembangkan dan memajukan wilayah pedesaan terutama daerah yang masih tertinggal. Berdasarkan pasal 19 Undang-Undang nomor 6 tahun 2014, Desa diberikan kewenangan yang mencakup:

1. Kewenangan berdasarkan hak asal usul.

2. Kewenangan lokal berskala desa.

3. Kewenangan yang ditugaskan oleh Pemerintah, Pemerintah Daerah Provinsi, atau Pemerintah Daerah Kabupaten/Kota, dan

4. Kewenangan lain yang ditugaskan oleh Pemerintah, Pemerintah Daerah Provinsi, atau Pemerintah Daerah Kabupaten/Kota sesuai dengan ketentuan peraturan perundang-undangan.
Dari permasalahan tersebut diadakannya otonomi desa, diharapkan desa lebih bisa berkembang dengan diberikannya wewenang untuk mengurus rumah tangganya sendiri, akan tetapi sebagai konsekuensi logis adanya kewenangan dan tuntutan dari pelaksanaan otonomi desa adalah tersedianya dana yang cukup.

Pembiayaan atau keuangan merupakan faktor esensial dalam mendukung penyelenggaraan otonomi desa, sebagaimana juga pada penyelenggaraan otonomi daerah. Maka untuk mengatur dan mengurus rumah tangganya sendiri desa membutuhkan dana atau biaya yang memadai sebagai dukungan pelaksanaan kewenangan yang dimilikinya.

Dana desa merupakan dana yang didapat desa untuk menyelenggarakan untuk program pemerintahan, program pembangunan, program pemberdayaan masyarakat dan program pembinaan masyarakat. Akan tetapi tahun 2016 prioritas penggunaan dana desa masih diutamakan untuk mendanai program atau kegiatan program pelaksanaan pembangunan desa dan pemberdayaan masyarakat desa.

Provinsi Sulawesi Utara merupakan Provinsi paling utara di Indonesia. Provinsi Sulawesi Utara memiliki 11 Kabupaten dan 4 Kota. Salah satu Kabupaten yang ada di Provinsi Sulawesi Utara adalah Kabupaten Minahasa. Kabupaten Minahasa memiliki 25 Kecamatan dengan luas wilayah $1.114,87 \mathrm{~km}^{2}$ salah satu Kecamatan yang ada Di Minahasa adalah Kecamatan Sonder yang memilik 19 Desa dengan luas wilayah $46,80 \mathrm{~km}^{2}$. Prioritas penggunaan dana desa di Kecamatan Sonder mengikuti Permendesa PDTTrans nomor 21 tahun 2015 tentang Prioritas Penggunaan Dana Desa tahun 2016 untuk program pembangunan dan pemberdayaan.

Berdasarkan ketentuan yang ada dokumen RPJMdes dan RKPdes membuat analisa masalah, peta potensi dan aset serta perencanaan program fisik desa untuk menjawab permasalahan yang ada di desa. Tujuan utama pemerintah dalam pemberian bantuan dana desa adalah meningkatkan kesejatraan dan pemerataan pembangunan desa melalui peningkatan pelayanan publik desa, memajukan perekonomian, mengatasi kesenjangan pembangunan antar desa dan memperkuat masyarakat desa sebagai subjek dari pembangunan. 
Dalam hal ini peneliti akan meneliti Bagaimana Penggunaan dana desa dalam program Pemberdayaan Masyarakat Desa di Kecamatan Sonder tahun 2016. Dana Desa merupakan sebuah program yang jika dijalankan dengan baik memiliki pengaruh yang sangat besar terhadap pemberdayaan masyarakat baik dalam segi kegiatan, kesehatan, pendidikan maupun dalam kegiatan pemberdayaan lainnya di sebuah Desa di setiap Kabupaten di Indonesia, khususnya di Kecamatan Sonder. Kendali dalam program ini juga sepenuhnya ditangani secara swadaya oleh pemerintahan desa dan juga masyarakat. Oleh sebab itu, peneliti lebih memilih meneliti mengenai program ini karena jika dana ini dikelola dengan baik dan jujur, maka hasil akan terlihat jelas dalam segi kegiatan dan pemberdayaan.

Di Kecamatan Sonder terdiri dari 19 Desa. Namun hanya 8 Desa yang bersedia memberikan informasi berupa dokemen APBDES untuk menunjang penelitian ini yaitu Desa Rambunan, Tonelet, Tonelet 1, Kolongan Atas 2, Kauneran, Kauneran 1, Talikuran, dan Desa Leilem 3.

\section{Pemberdayaan Masyarakat}

Menurut Wahjudin Sumpeno (2011) pemberdayaan adalah upaya yang di lakukan oleh unsur yang berasal dari luar tatanan terhadap suatu tatanan, agar tatanan tersebut mampu berkembang secara mandiri. Dengan kata lain, pemberdayaan sebagai upaya perbaikan wujud interkoneksitas yang terdapat di dalam suatu tatanan dan atau upaya penyempurnaan terhadap elemen atau komponen tatanan yang ditujukan agar tatanan dapat berkembang secara mandiri. Jadi pemberdayaan adalah upaya yang di tujukan agar suatu tatanan dapat mencapai suatu kondisi yang memungkinkan untuk membangun dirinya sendiri.

Tujuan pemberdayaan masyarakat menurut Sumaryadi (2005) pada dasarnya yaitu untuk membantu pengmbangan manusiawi yang otentik dan integral dari masyarakat yang lemah, miskin, marjinal dan kaum kecil serta untuk memberdayakan kelompok masyarakat tersebut secara sosio ekonomis sehingga mereka dapat lebih mandiri dan dapat memenuhi kebutuhan dasar hidup mereka namun sanggup berperan serta dalam pengembangan masyarakat.
Menurut Sumodiningrat (1999), bahwa pemberdayaan masyarakat merupakan upaya untuk memandirikan masyarakat lewat perwujudan potensi kemampuan yang mereka miliki. Adapun pemberdayaan masyarakat senantiasa menyangkut dua kelompok yang saling terkait, yaitu masyarakat sebagai pihak yang diberdayakan dan pihak yang menaruh kepedulian sebagai pihak yang memberdayakan.

\section{Rumusan Masalah}

Berdasarkan uraian diatas dirumuskan permasalahan yang menjadi fokus penelitian lebih mendalam yaitu:

1. Jenis-jenis kegiatan yang dibiayai oleh dana desa untuk program fisik dan program pemberdayaan.

2. Jumlah Alokasi dana desa untuk program fisik dan program pemberdayaan.

3. Pendapat Masyarakat terhadap penggunaan dana desa.

\section{Tujuan Penelitian}

1. Mengidentifikasi jenis program yang dibiayai oleh dana desa.

2. Mengetahui Alokasi penggunaan Dana Desa dalam program fisik dan program pemberdayaan Di Kecamatan Sonder Kabupaten Minahasa.

3. Mengetahui pendapat Masyarakat terhadap penggunaan dana desa.

\section{Manfaat Penelitian}

1. Penelitian ini akan menambah pengetahuan masyarakat akan kebijakan pemerintah dalam penggunaan dana desa.

2. Penelitian ini dapat dijadikan sebagai sumber informasi untuk menambah pengetahuan mengenai kebijakan penggunaan Dana Desa.

\section{METODE PENELITIAN}

\section{Lokasi dan Waktu Penelitian}

Lokasi Penelitian ini di lakukan di Kecamatan Sonder Kabupaten Minahasa. Waktu penelitian berlangsung selama 2 bulan, mulai bulan Oktober sampai bulan November 2018. 


\section{Jenis Data dan Sumber Data}

Jenis data yang digunakan dalam penelitian ini adalah data Primer dan Sekunder.

Data Primer yaitu data yang diperoleh dengan melakukan survei wawancara langsung kepada responden dalam hal ini Masyarakat menggunakan kuesioner. Data sekunder yaitu data yang bersumber atau diperoleh dari kantor dan institusi yang terkait dengan penelitian ini kantor desa berupa dokumen APBDes tahun 2016 yang diperoleh dari Hukum Tua yang ada di 8 Desa.

\section{Metode Pengambilan Sampel}

Penentuan sampel lokasi penelitian dengan metode purposive sampling atau secara sengaja terhadap 8 Desa di Kecamatan Sonder desa tersebut yakni:

1) Desa Leilem 3

2) Desa Kolongan Atas 2

3) Desa Tonelet

4) Desa Tonelet 1

5) Desa Talikuran 1

6) Desa kauneran,

7) Desa Kauneran 1

8) Desa Rambunan.

Penentuan sampel diambil dari 8 Desa dengan metode Accidental Sampling. Menurut Sugiono (2008), Accidental Sampling adalah Teknik penentuan sampel berdasarkan kebetulan, yaitu Masyarakat yang secara kebetulan bertemu dengan peneliti di gunakan sebagai sampel Masyarakat dari 8 Desa terpilih setiap desa di ambil 4 sampel sehingga jumlah sampel masyarakat yang di wawancarai berjumlah 32 sampel.

\section{Konsep Pengukuran Variabel}

Variabel yang diukur dalam penelitian ini adalah

1. Jenis program yang dibiayai oleh dana desa.

2. Jenis kegiatan untuk program fisik dan program pemberdayaan.

3. Perbandingan anggaran program fisik maupun program pemberdayaan masyarakat (\%)

4. Pendapat Masyarakat mengenai kesesuaian program dan implementasinya (\%), terdiri dari beberapa pertanyaan:

a) Keterbukaan Pemerintah Desa Tentang Dana Desa Kepada Masyarakat (Setuju/Tidak Setuju).

b) Pendapat Masyarakat tentang kesesuaian Penggunaan Dana Desa untuk Program Pembangunan (Setuju/Tidak Setuju).

c) Pendapat Masyarakat Tentang kesesuaian Program Pembangunan (Setuju/Tidak Setuju).

\section{Metode Analisis Data}

Penelitian ini menggunakan metode analisis deskriptif. Metode deskriptif merupakan metode penelitian yang digunakan untuk menggambarkan masalah yang pada masa sekarang atau yang sedang berlangsung saat penelitian.

\section{HASIL DAN PEMBAHASAN}

\section{Deskripsi Wilayah Penelitian}

Kecamatan Sonder merupakan salah satu kecamatan yang terdapat di Kabupaten Minahasa dengan Luas wilayah $46.80 \mathrm{~km}^{2}$ yang terdiri dari 19 Desa, adapun batas-batas Kecamatan Sonder sebagai berikut:

1. Sebelah Utara : Kota Tomohon

2. Sebelah Timur : Kecamatan Romboken

3. Sebelah Selatan : Kecamatan Kawangkoan

4. Sebelah Barat : Kecamatan Suluun Tareran (Kabupaten Minahasa Selatan)

Total keseluruhan jumlah penduduk yang berada di Kecamatan Sonder berjumlah 18.064 jiwa.

Tabel 1. Jumlah Penduduk Berdasarkan Jenis Kelamin.

\begin{tabular}{cccc}
\hline No & $\begin{array}{c}\text { Jenis } \\
\text { Kelamin }\end{array}$ & $\begin{array}{c}\text { Jumlah Penduduk } \\
\text { (Orang) }\end{array}$ & $(\%)$ \\
\hline 1. & Laki-Laki & 9.135 & 50,57 \\
2. & Perempuan & 8.929 & 49,43 \\
\hline & Jumlah & 18.064 & 100 \\
\hline
\end{tabular}

Sumber: Badan Pusat Statistik Kabupaten Minahasa, 2014.

Tabel 1 menunjukkan jumlah penduduk berjenis kelamin Laki-Laki di kecamtan Sonder berjumlah 9.135 jiwa atau 50,57 persen dan jumlah penduduk berjenis kelamin perempuan di Kecamatan Sonder berjumlah 8.929 jiwa atau 49,43 persen di Kecamatan Sonder.

Kecamatan Sonder merupakan salah satu sentra penghasil cengkih di Sulawesi Utara. Bahasa daerah yang digunakan orang Sonder adalah bahasa Tontemboan yang merupakan salah satu bahasa daerah Minahasa.

Kantor Camat Kecamatan Sonder berada di Desa Talikuran, terminal dan pasar besar terdapat di desa Kauneran di Sonder juga terdapat rumah sakit tertua di Indonesia Timur yang berdiri sejak tahun 1901 yakni rumah sakit Siloam, yang terletak di Desa Kolongan Atas. Sonder juga memiliki tempat wisata seperti Taman Toar Lumimuut, Air Terjun Tincep dan Arum Jeram Timbukar. 


\section{Jenis Program Yang di Biayai oleh Dana Desa di Kecamatan Sonder.}

Penggunaan dana desa di 8 Desa yang ada di Kecamatan Sonder mengacu pada Permendesa PDTTrans nomor 21 tahun 2015 tentang Prioritas Penggunaan Dana Desa tahun 2016 Penggunaan Dana Desa untuk prioritas program Pembangunan Desa dan Pemberdayaan Masyarakat Desa sebagaimana dimaksud dalam Pasal 4, menjadi prioritas kegiatan, anggaran dan belanja desa yang disepakati dan diputuskan melalui musyawarah desa sehingga. Dapat diartikan bahwa fokus penelitian ini adalah untuk program pembangunan dan program pemberdayaan.

Dalam pengambilan data tentang penggunaan dana desa dapat dijadikan gambaran dalam penggunaan dana desa, merupakan data yang bisa dipertanggung jawabkan yang bersumber dari dokumen APBDES yang di berikan Pemerintah Desa di 8 Desa, 11 Desa lainnya tidak di jadikan sampel penggunaan dana desa karena kurang terbukanya pemerintah desa, alasan Pemerintah Desa di 11 Desa yang tidak dapat memberikan dokumen APBDES karena menurut mereka Dokumen APBDES merupakan dokumen milik desa.

Anggaran yang paling besar untuk program fisik untuk yakni untuk mebiayai kegiatan pekerjaan jalan lapis sirtu dengan anggaran Rp. 863.829.700 dan kegiatan yang menggunakan anggaran paling kecil yakni kegiatan pekerjaan bak air dengan anggaran $\mathrm{Rp}$ 14.495.500.

Dari 14 jenis kegiatan yang ada ada 2 jenis kegiatan yang sama dilakukan di 8 Desa yaitu kegiatan penerangan jalan umum dan kegiatan pekerjaan tugu batas desa. Desa Rambunan merupakan desa yang paling banyak memiliki anggaran untuk program fisik dengan anggaran sebesar Rp. 596.793.300. Desa Rambunan juga merupakan desa yang paling banyak kegiatan untuk program fisik dengan 9 jenis kegiatan dan desa yang memiliki anggaran paling kecil yakni Desa Talikuran 1 dengan anggaran Rp 542.063.700.

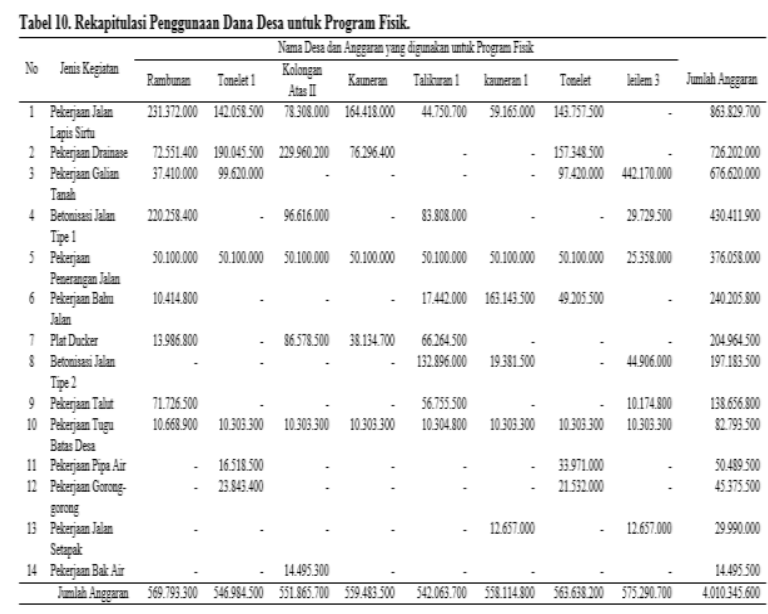

Tabel ll. Rekapitulasi Penggunaan Dana Desa Dalam Program Pemberdazaan.

\begin{tabular}{|c|c|c|c|c|c|c|c|c|c|c|}
\hline \multirow[b]{2}{*}{6} & \multirow[b]{2}{*}{ laim Regitan } & \multicolumn{8}{|c|}{ 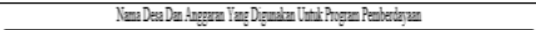 } & \multirow[b]{2}{*}{ habh hegren } \\
\hline & & Prahnen & Towela! & $\begin{array}{c}\text { Rologen } \\
\text { Atas? }\end{array}$ & $\operatorname{lngan}$ & Thren 1 & Rezan! & Twelt & Lelan? & \\
\hline & 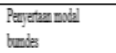 & 10000000 & 4000000 & 2000000 & 5500000 & (55000000 & 35000000 & 21000000 & 2000000 & 39000000 \\
\hline & $\begin{array}{l}\text { Rethanpega } \\
\text { petring }\end{array}$ & 1500000 & 5000000 & 2000000 & 750000 & 500000 & 900000 & 5500000 & . & 73500000 \\
\hline & Bisthinatia & 800000 & 8000000 & 800000 & 800000 & 80000 & 800000 & 800000 & 800000 & 6800000 \\
\hline & Bumpargat Dea & 8000000 & 8000000 & 8000000 & 800000 & 80000 & 800000 & 8000000 & 800000 & 68000000 \\
\hline & $\begin{array}{l}\text { Sodtadingthm } \\
\text { ta }\end{array}$ & 650000 & 6500000 & 6500000 & 650000 & 650000 & 6500000 & 6500000 & 650000 & 52000000 \\
\hline 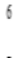 & $\begin{array}{l}\text { Sofitafingprastith } \\
\text { des }\end{array}$ & 650000 & 650000 & 6500000 & 6500000 & 650000 & 6500000 & 6500000 & 650000 & 52000000 \\
\hline & Sutj batign PXX & 650000 & 650000 & 650000 & 650000 & 650000 & 650000 & 6500000 & 650000 & 5200000 \\
\hline 8 & Paputhan deas & 4604000 & 464000 & 462400 & 464000 & 464000 & 4.04000 & 464000 & 464000 & 3692000 \\
\hline y & Pagehlor posyath & 4900000 & 5062200 & 361000 & 30430 & 304300 & 1200000 & 304300 & 300000 & 3202030 \\
\hline 10 & Butaytang & 3.000000 & 8000000 & & & - & 5000000 & 6000000 & 3000000 & 25000000 \\
\hline 11 & 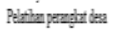 & 3000000 & 3000000 & 3000000 & 30000 & 3.0000 & 300000 & 3000000 & 30000 & 24000000 \\
\hline 12 & Plathan BPD & 2800000 & 2800000 & 2000000 & 2000000 & 2800000 & 2800000 & 2800000 & 2000000 & 2240000 \\
\hline 15 & 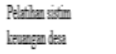 & 2800000 & 2800000 & 2000000 & 200000 & 280000 & 2800000 & 2800000 & 2000000 & 22100000 \\
\hline 14 & Pellinhingta & & & & 450000 & 500000 & & 5000000 & & 950000 \\
\hline 15 & Regien lech deas & & & & 150000 & & & & 4000000 & 5500000 \\
\hline & 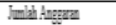 & 500 & 96891.700 & 1167.72300 & 107.7920 & 1117963300 & 9280200 & 8955000 & 6994000 & 7DI.MSIO \\
\hline
\end{tabular}

Tabel 11 menunjukkan bahwa penggunaan dana desa pada tahun 2016 untuk Program Pemberdayaan di 8 desa di Kecamatan Sonder terdapat 15 jenis kegiatan Pemberdayaan Desa, terdiri dari kegiatan Penyertaan Modal Bumdes, Ketahanan Pangan Pertanian, Bimtek Hukum Tua, Bimtek Perangkat Desa, Studi Banding Hukum Tua, Studi Banding Perangkat Desa, Studi Banding PKK, Perpustakaan Desa, Pengelolaan Posyandu, Budidaya Tanaman, Pelatihan Perangkat Desa, Pelatihan BPD, Pelatihan Sistim Keuangan Desa, Pemilihan Hukum Tua dan Kegiatan Lomba Desa yang dibiayai oleh dana desa dengan total dana sebesar Rp 787.494.500, dengan kegiatan pengelolaan badan usaha milik desa atau bumdes memiliki dana yang paling besar yakni Rp 239.000.000 dan kegiatan lomba desa merupakan kegiatan yang paling sedikit dalam penggunaan dana desa untuk programPpemberdayaan yakni $\mathrm{Rp}$ 5.500.000.

Penggunaan dana desa untuk program pemberdayaan dengan kegiatan badan usaha milik desa yang paling banya biaya dikarenakan badan usaha milik desa bertujuan agar terciptanya peningkatkan pendapatan desa itu sendiri.

Data diatas menunjukkan penggunaan dana desa tahun 2016 di 8 desa yang merupakan gambaran penggunaan dana desa di Kecamatan Sonder penggunaan dana desa difokuskan untuk program fisik dan pemberdayaan. Untuk program fisik dari data APBDES yang ada di 8 Desa jenis-jenis kegiatan yang ada di 8 Desa berfariasi sesuai dengan kebutuhan yang ada di Desa. Penggunaan dana desa untuk program fisik bertujuan agar supaya terjadinya pemerataan pembangunan di Desa agar supaya kedepannya terjadinya peningkatan perekonomian masyarakat karena adanya pembangunan sarana prasaran yang menunjang perekonomian masyarakat itu sendiri. 
Untuk penggunaan dana desa untuk program pemberdayaan hampir semua kegiatan yang ada di 8 Desa yang ada di Kecamatan Sonder jenis kegiatannya hampir sama dikarenakan untuk prioritas penggunaan dana desa untuk program pemberdayaan difokuskan untuk memperkuat kelembagaan yang ada di Desa agar supaya dalam penyusunan perencanaan pembangunan bisa berjalan dengan baik.

\section{Perbandingan Anggaran Program Fisik Maupun Program Pemberdayaan Masyarakat.}

Tabel 12 menunjukkan bahwa penggunaan dana desa di 8 Desa yang data di ambil dari APBDes tahun 2016 menunjukkan penggunaan dana untuk program pembangunan 85,11 persen dana desa dari 8 Desa yang datanya di ambil dari APBDes tahun 2016 penggunaannya digunakan untuk program pembangunan sedangkan untuk program pemberdayaan 14,88 persen. Dapat diartikan bahwa penggunaan dana desa di 8 Desa bertujuan untuk pembangunan infrastruktur desa karena sebagian besar penggunaan dana desa membiayai program fisik desa.

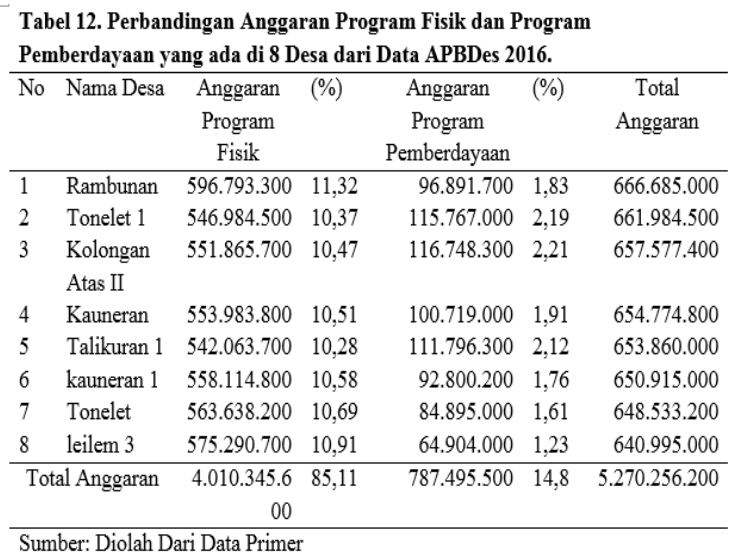

\section{Pendapat Masyarakat Tentang Kesesuaian Program dan Implementasinya}

Pendapat masyarakat tentang penggunaan dana desa di 8 desa kecamatan sonder berfariasi di karenakan ada masyarakat yang beranggapan pemerintah desa telah melakukan program sudah sesuai dengan keinginan masyarakat ada pula yang beranggapan pemerintah desa belum mampu menjalankan program dengan baik.

\section{Keterbukaan Pemerintah Desa Tentang Dana Desa Kepada Masyarakat}

Tujuan dari pengalokasian dana desa diantaranya adalah untuk meningkatkan penyelenggaraan pemerintah desa dalam melaksanakan pelayanan pemerintahan, pembangunan, dan kemasyarakatan sesuai dengan kewenangannya. Selain itu dana desa ini ditujukan pula supaya dapat meningkatkan kemampuan lembaga kemasyarakatan di Desa dalam perencanaan, pelaksanaan, dan pengendalian pembangunan secara partisipasi sesuai dengan potensi yang dimiliki oleh desa. Dari tujuan tersebut penggunaan dana desa haruslah ada keterbukaan dari pemerintah desa kepada masyarakat agar penggunaan dana desa bisa diketahui bukan hanya dari pemerintah desa tapi juga masyarakat, berikut ini merupakan pendapat masyarakat tentang keterbukaannya Pemerintah Desa tentang penggunaan dana desa kepada Masyarakat.

Tabel 13. Pendapat Masyarakat Tentang keterbukaan penggunaan Anggaran Dana Desa dari Pemerintah Desa.

\begin{tabular}{llll}
\hline No & $\begin{array}{l}\text { Pendapat } \\
\text { Responden }\end{array}$ & Jumlah Responden & $(\boldsymbol{\%})$ \\
\hline 1 & Setuju & 22 & 68,75 \\
2 & Tidak Setuju & 10 & 31,25 \\
\hline & Jumlah & 32 & 100 \\
\hline
\end{tabular}

Sumber: Diolah dari Data Primer

Dapat dijelaskan bahwa 22 responden menyatakan bahwa mereka setuju dengan keterbukaan pemerintah desa tentang penggunaan anggaran dana desa, karena dilakukannya sosialisasi dari pemerintah desa tentang penggunaan anggaran dana desa. Sedangkan 10 responden menyatakan tidak setuju dengan keterbukaan pemerintah desa akan penggunaan anggaran dana desa karena kurangnya sosialisasi dari pemerintah desa tentang penggunaan anggaran dana desa.

Hasil penelitian ini menunjukkan bahwa 68,75 persen responden (22 responden) memilih setuju adalah responden yang sudah perna mengikuti musyawah desa dan aktif dalam kegiatan sosial masyarakat, dan 31,25 persen (10 responden) yang memilih tidak setuju merupakan mereka yang sudah pernah diundang untuk mengikuti musyawarah desa, akan tetapi responden tersebut tidak mengikuti musyawarah desa dan kurang aktif dalam kegiatan sosial masyarakat. 
Pendapat Masyarakat Tentang Kesesuaian Penggunaan Dana Desa Untuk Program Pembangunan

Pendapat masyarakat tentang penggunaan dana untuk program pembangunan desa di 8 Desa yang ada di Kecamatan Sonder bervariasi di karenakan ada masyarakat yang beranggapan pemerintah desa telah melakukan program sudah sesuai dengan keinginan masyarakat ada pula yang beranggapan pemerintah desa belum mampu menjalankan program dengan baik.

Tabel 14. Pendapat Masyarakat tentang penggunaan Dana Desa untuk Program Pembangunan.

\begin{tabular}{cccc}
\multicolumn{4}{c}{ Desa untuk Program Pembangunan. } \\
\hline No & $\begin{array}{c}\text { Pendapat } \\
\text { Responden }\end{array}$ & Jumlah Responden & $\mathbf{( \% )}$ \\
\hline 1 & Setuju & 24 & 75 \\
2 & Tidak Setuju & 8 & 25 \\
\hline & Jumlah & 32 & 100 \\
\hline
\end{tabular}

Sumber: Diolah Dari Data Primer.

Tabel 14 menunjukkan bahwa 24 responden atau setara dengan 75 persen menyatakan setuju dengan penggunaan dana desa untuk program pembangunan, dikarenakan program pembangunan sangat perlu untuk peningkatan fasilitas desa guna penunjang ekonomi masyarakat dan, dan yang tidak setuju dengan program pembangunan ada 8 responden atau setara dengan 25 persen dikarenakan terbatasnya anggaran dana desa untuk program pembangunan pada akhirnya tidak sesuai yang diharapkan mereka tentang program pembangunan.

\section{Pendapat Masyarakat Tentang kesesuaian Program Pembangunan}

Pendapat masyarakat tentang kesesuaian program program pembangunan berfariasi dalam hal ini ada pendapat yang setuju adapula yang tidak setuju tentang kesesuaian program pembangunan atau harapan masyarakat mengenai pemabangunan yang ada.

Tabel 15. Pendapat Masyarakat tentang Perencanaan Program Pembangunan.

\begin{tabular}{llll}
\hline No & $\begin{array}{l}\text { Pendapat } \\
\text { Responden }\end{array}$ & Jumlah Responden & (\%) \\
\hline 1 & Setuju & 25 & 78,12 \\
2 & Tidak Setuju & 7 & 22,88 \\
\hline & Jumlah & 32 & 100
\end{tabular}

Sumber: Diolah dari Data Primer
Tabel 15 menunjukkan bahwa dari 25 responden setuju dengan pembangunan yang dilakukan pemerintah sudah sesuai dengan perencanaan dan yang tidak setuju berjumlah 7 responden. Pernyaataan ini dapat kita artikan bahwa menurut masyarakat bahwa pembangunan yang dilakukan pemerintah desa yang ada di 8 Desa untuk program pembangunan sudah sesuai dengan perencanaan karena dari 32 responden yang ada di 8 Desa menyatakan apa yang yang telah di programkan pemerintah desa untuk program pembangunan sudah direncanakan terlebih dan sesuai apa yang diharapkan dan yang tidak setuju dengan program pembangunan ada 7 responden atau setara dengan 22,88 persen beranggapan ada beberapa jenis kegiatan program pembangunan yang telah dijalankan tidak sesuai dengan apa yang direncanakan karena sebagian kegiatan tidak dijalankan dengan baik.

\section{KESIMPULAN DAN SARAN}

\section{Kesimpulan}

Berdasarkan hasil penelitian Kajian Penggunaan Dana Desa Dalam Program Pemberdayaan Masyarakat yang ada di Kecamatan Sonder sebagai berikut:

1. Penggunaan dana desa di Kecamatan Sonder khusunya di 8 Desa digunakan untuk Program Fisik berjumlah 14 jenis kegiatan yakni kegiatan pekerjaan Jalan Lapis Sirtu, Pekerjaan Drainase, Pekerjaaan Galian Tanah, Betonisasi Jalan Tipe 1, Pekerjaan Penerangan Jalan, Pekerjaan Bahu Jalan, Plat Ducker, Betonisasi Jalan Tipe 2, Pekerjaan Talut, Pekerjaan Tugu Batas Desa, Pekerjaan Pipa Air, Pekerjaan Gorong-Gorong, Pekerjaan Jalan Setapak, Pekerjaan Bak Air, kegiatan Program Pemberdayaan berjumlah 15 jenis kegiatan yakni Penyertaan Modal Bumdes, Ketahanan Pangan Pertanian, Bimtek Hukum Tua, Bimtek Perangkat Desa, Studi Banding Hukum Tua, Studi Banding Perangkat Desa, Studi Banding PKK, Perpustakaan Desa, Pengelolaan Posyandu, Budidaya Tanaman, Pelatihan Perangkat Desa, Pelatihan BPD, Pelatihan Sistim Keuangan Desa, Pemilihan Hukum Tua dan Kegiatan Lomba Desa. 
2. Penggunaan dana desa yang terbesar digunakan untuk kegiatan pekerjaan jalan lapis sirtu dan yang memliki anggaran paling sedikit untuk program pembangunan yakni kegiatan pekerjaan bak air. Untuk program pemberdayaan Penyertaan Modal Bumdes memiliki anggaran yang paling besar dan untuk penggunaan dana desa untuk program pemberdayaan Kegiatan Lomba Desa memiliki anggaran paling sedikit yang diambil dari dokumen APBDES. Desa Rambunan merupakan desa yang paling banyak dalam penggunaan dana desa dan desa penggunaan dana desa untuk program pemberdayaan banyak digunakan untuk kegiatan penyertaan modal bumdes dan kegiatan yang paling kecil dalam penggunaan dana desa untuk program pemberdayaan yakni kegiatan lomba desa. yang paling sedikit dalam penggunaan anggaran dana desa yakni Desa Talikuran 1 .

3. $68,75 \%$ masyarakat menyatakan setuju dengan keterbukaan dari pemerintah desa akan penggunaan dana desa. $75 \%$ masyarakat menyatakan setuju setuju dengan penggunaan dana desa untuk program pembangunan. $\quad 78,12 \%$ masyarakat berpendapat tentang kesesuaian program pembangunan telah sesuai dengan apa yang diharapkan.

\section{Saran}

1. Dalam rencana penyusunan program kegiatan untuk program pembangunan dan program pemberdayaan haruslah melihat apa yang menjadi prioritas dalam melaksanakan kegiatan dan haruslah sesuai dengan kebutuhan masyarakat guna peningkatan ekonomi masyarakat.

2. Perlu adanya peningkatan anggaran untuk kegiatan penyertaan modal BUMDES dan kegiatan ketahanan pangan untuk menunjang perokonomian desa dan masyarakat.

3. Dalam penggunaan dana desa perlu ditingkatkan akan keterbukaan dari pemerintah akan penggunaan dana desa.

\section{DAFTAR PUSTAKA}

Sugiono. 2008. Metode Penelitian Kuantitatif Kualitatif dan R\&D. Alfabeta. Bandung.

Sumaryadi. 2005. Perencanaan Pembangunan Daerah Otonom dan Pemberdayaan Masyarakat. CV Citra Utama. Jakarta.

Sumodiningrat, $1999 . \quad$ Pemberdayaan Masyarakat dan Jaringan Pengaman Sosial, PT Gramedia Pustaka Utama, Jakarta.

Sumpeno W. 2011. Perencanaan Desa Terpadu. Edisi Kedua. Reinforcement Action and Development. Banda Aceh. 